\title{
Świat wspomnień Ewy Felińskiej z Wendorffów
}

\author{
Agata Roćko
}


nAPNS Seria IX 20103

\section{Agata Roćko}

\section{Świat wspomnień Ewy Felińskiej z Wendorffów}

$E^{\infty}$ wa z Wendorffów Feliníska (1793-1859) urodziła się w Uznozie w powiecie słuckim, na Litwie, w rodzinie szlacheckiej. Byla córką Zygmunta Wendorffa i Zofii z Sągajtlów. Mając osiemnaście lat (w 1811 roku), wyszła za mąż za Gerarda Felińskiego, brata Alojzego Felińskiego - autora Barbary Radziurittón'ny. Mimo iz jest autorką pięciu powieści obyczajowych (Hersylia, Pan Deputat, Siostrzenica i ciotka, Wigilia Non'ego Rokm, Pomyłka) oraz kilku artykułów i drobnych utworów, rozgłos przyniosły jej dopiero wspomnienia. Pisać i publikować zaczęła późno, w ostatnim piętnastoleciu swego życia. Ważną rolę w jej działalności pisarskiej odegrał Józef Ignacy Kraszewski, który przychylnie odniósl się do jej twórczości i przyczynił się do rozgłosu jej wspomnień z zesłania w latach 1839-1844 Wspommienia z podróży'do Bcrezou'a i Saratou'a, początkowo drukowanych we fragmentach na łamach „Athenaem” w latach 1845-1849. Całość w redakcji zmienionej i znacznie powiększonej wydano w Wilnie w latach 1852-1853. Niedługo po tym pojawiły się przekłady na język angielski (Londyn 1852, 1853. 1854) oraz duński (Kopenhaga 1855). Zachęcona powodzeniem autorka przystąpiła do opracowania wspomnień swego życia. Po pozytywnej ocenie Kraszewskiego wydano je w Wilnie jako Pamiętniki z życia Eu'y Feliniskicj, t. 1-3, 1856, i seria 2, t. 1-2, 1858-1859. Autorka zdolala je doprowadzić do 1821 roku. Pracę nad nimi przerwala śmierć Felińskiej w Wojutynie 20 XII $1859^{1}$.

Autorzy podręcznika akademickiego Romantyzm, Alina Witkowska i Ryszard Przybylski, pamiętnikarstwo Ewy Felińskiej zaliczają do kręgu wspommicń opisujących „czasy kontuszowe”, a w przypadku naszej autorki uznają, iż jej prace oddaja „kameralne życie prowincji”. Rzeczywiście, Pamiętniki... Felińskiej są doskonałym obrazem życia i obyczajów dworów i dworków na Litwie pod koniec XVIII wicku. Poza tym włączają jej wspomnienia w

'Zob. T. Turkowski, En'a Foliniska, w: Polski stommik biografic:m)' t. 6. Kraków 1948. s. 407-408. 
...nurt pamiętnikarstwa intymnego, zwróconego ku własnej podmiotowości i kameralnemu kręgowi życia. Doznania egzystencjalne, prywatność, sfera uczuć jednostkowych staną się ich wyróżnikiem, choć ani w zamierzeniu, ani w wykonaniu nie będą to jeszcze wyznania intymne².

Wydaje się, że powyższe stwierdzenia, wynikające z potrzeby syntezy koniecznej w uję-

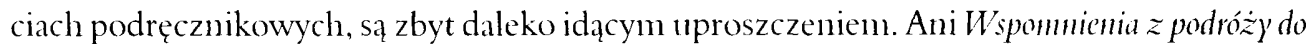
Berezou'a i Saratou'a, ani Pamiętniki ż̇łcia... nie należą do kręgu pamiętnikarstwa intymnego, które rzeczywiście również za sprawą kobiet (na przykład wspomnienia Wirydianny Fiszerowej) rozwija się w Polsce na przełomie XVIII i XIX wieku. Nawet Ewa Felińska zostala włączona za sprawą swojego pisarstwa wspomnieniowego do kręgu „pisarek polskich epok dawnych" ze względu na silne zakorzenienie w kulturze osiemnastego wieku, przywiązanie do tradycji opisu i relacji typowo ekstrawertywnej, występującej w wieku XVIII i wcześniej3.

Warto podkreślić, iż do interpretacji pamiętników i wspomnicń ważne jest zwrócenie uwagi na typ osobowości piszącego, a Ewa Felińska na podstawie jej wspomnień jawi się jako osoba zamkniçta, choć bardzo wrażliwa. Może właśnie dlatego, oprócz wychowania w tradycji staropolskicj, jej pamiętniki prawie nie ujawniają intymnych przeżyć i doznań. Raz zdarza się, iz autorka przy opisie swojej przeprowadzki z domu rodzinnego do domu Wendorffów w Holynce zakreśla swój obraz:

Byłam zawsze nieśmiała, zimmej powierzchowności, skupiając wewnątrz żar serca, zachowując uczucia dla oddalonych, które się rozrastały, olbrzymiały w ukryciu. In mniej świat zewnętrzny do mnie się uśmiechał, im mniej pieścil, tym życie wewnętrzne silniej się rozwijałot.

Jednak tego życia wewnętrznego nie poznajemy w sensie poznania owych intymnych przeżyć. Ale przedstawiony obraz prowincji litewskiej w Pamiętnikach... oraz obraz zesłania na osiedlenie do Berezowa, a potem Saratowa, we Wspomnieniach... osadzony jest w refleksjach religijnych, cywilizacyjnych, pedagogicznych, artystycznych. Sfera wewnętrznych przeżyć takich jak ból, cierpienie, miłość, stracl stanowią temat tabu, tak jakby miały zabrać ową wewnętrzną siłę, która ujawnia się mimo wszystko poprzez barwną opowieść, skreśloną z literackim zacięciem. Poza tym wspomnienia Felińskiej często dzieli duży dystans czasowy między momentem pisania a czasem przedstawianych wydarzení. Autorka, wspominając bolesne fakty ze swego życia, jakby nie chciała przeżywać ich na nowo, dlatego często zaznacza:

2 A. Witkowska, R. Przybylski, Romanty=m, Warszawa 1997. s. 617.619.

${ }^{3}$ Zub. J. Rudnicka. Eu'a Feliniska - pamiętmikarka, w: Pisarki polskic epok dau'mych, red. K. Stasicwicz, Olsztyn 1998, s. 193-200. Jadwiga Rudnicka (w przypisic 29 do swego artykulu) pisze: "W Bibliografii literatury' polskiej Felińska miéści siç w tomic "romantycznym". Ze względu na osobowość i prace literackie powimna ona być w'śród ludzi oświecenia, analogicznic do Klementyny z Tańskich Hoffinanowej”.

${ }^{+}$E. Felińska. Pamiętniki ż́jcia... t. 1, Wilno 1856. s. 159): pozostale cytaty pochodzą z tegoż wydania. 
Nie ma co mówić o żalu, łzach, smutku. Malo kto nie przechodzil przez bolesne koleje, więc latwo je wyobrazić (Paniętniki, t. 2, s. 326).

O wiele krótszy dystans dzieli czas powstania wspomnień z pobytu w Berezowie i Saratowie, dlatego bogatsze są w refleksje bardzicj osobiste, choć nie intymne. Ale w okresie swego zesłania autorka przeżywa ogromną tragedię - śmierć córki Pauliny, i jest to jedyny moment, kiedy w jej pamiętnikarstwic pojawia się warstwa intymistyczna, jednoczéśnie jẹzyk opisı staje się bardziej metaforyczny, ujawniają się myśli, rozmowy z Bogiem:

Wietrzyk, lagodnie muskając po twarzy, niby matka, co pieści dziecię zasmuncone, zdaje się szeptać do ucha: ,ja płynę z niebieskiej krainy, przynoszę ci stantąd nowiny; tam tak dobrze, tak cicho, tam wieczna pogoda, wieczna wiosna, tam radość bez goryczy i dni bez końca. Wartoż żałować życia? Wartoż za nim plakać?".

Modlitwa, samotność, cisza przyrodzenia wywarly wpływ na uczucia. Łzy wprawdzie płynęły jeszcze, ale ich źrzódło muicj było gorzkie, mniej wzburzone. Myśli zaczęły wychodzić z zamętu i inną przybierać barwę. Światto rzucone $z$ wysoka, inaczej oświecając ziemskie przedmioty, w innym przedstawiając świetle, inną też wartość onym nadawato.

W istocie pomyśliłam sobie: kto wie, czy Bóg, cofając dziecku memu dar życia tak na krótko udzielony, nie wyświadczyl jej prawdziwego dobrodziejstwa? Może zasłonił przed większymi cierpieniami. Jej życie było niby napiętnowane krzyżem. Młodość, ta pora, która dla każdego świeci we wstępie żywota różowym promieniem, dla niej przeszła w cierpieniach i trudach. Możnaż się spodziewać, że jej wróci lato, czego nie dala wiosna? $\mathrm{O}$, nie ${ }^{5}$.

Wsponnienia z podróży do Sybrrii, poby'tu u' Berezou'ie i Saratou'ic wprowadziły Ewę Felińską w krąg literatury zsylkowej. Wspomnienia nie mają martyrologicznego charakteru, co w dużym stopniu (poza osobowością) wynika z faktu publikowania ich pod cenzurą rosyjską. Felińską aresztowano za udzial w spisku Szymona Konarskiego, była sekretarką do korespondencji zagranicznej, znała liczne kontakty, dlatego aresztowano ją w 1838 roku, oderwano od wcześniej osieroconych przez ojca sześciorga dzieci, i po ośmioniesięcznym śledztwie w Wilnie i Kijowie skazano na osiedlenie na Syberii. Przebywała początkowo w Berezowie nad rzeką Ob (1839-1841), później w Saratowie nad Wołgą (1841-1844)".

Prowadzony na bieżąco w Berezowie i Saratowie dziemnik poprzedzony został relacja pamiętnikarską o podróży do Tobolska i pobycie w tym mieście. Autorka podkreśla nawet czas pisania wspomnień:

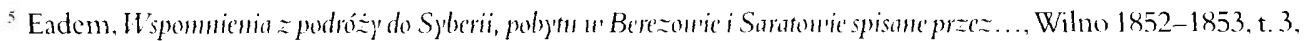
s. 14; wszystkic pozostake cytaty pochodzą z tegoż wydania.

"Zob. T. Turkowski, op. cit., s. 4()8. Zob. tez: Bibliografia literatury polskicj "Nou']' Korbut", t. 7, red. I. Śliwińska, S. Slupkicwicz i zesp., Warszawa 1968, s. 322. 
...bowiem wrażenia schwycone w przelocie notowalam tylko w pamięci, nie mając pod ręką ani papieru, ani pióra dla zatrzymania odebranych wrażeń (Wspommicnia, t. 1, s. 25).

Może dlatego opis zesłania często przybiera charakter metaforyczny. Podróż staje się snem, koszmarem, w który Felińska zagłębia się ponownie, przywołując w pamięci na przyklad dźwięk dzwonka pocztowego:

Zatrzymanie się przed domem pocztowym dla przemiany koni lub wywrót przywoływały na chwilę uwagę na rzeczy zewnętrzne, wtenczas ból głowy, ból członków wyraźniej czuć się dawaly, lecz krótkie chwile przeprzęgów nie zostawiały dość czasu wolnego na opamiętywanie się, bo gdy tętnienie dzwonka dalo hasło, sanie zaczynaty lecieć, na nowo zagłębiając się, to wyskakując z owych śniegowych przepaści, bez oddechu, bez zwolnienia kroku, tak coraz dalej, dalej, dalej... Dzień podawał nocy, a noc dniowi owe tętnienie dzwonka (Wspommienia, t. 1, s. 6).

Powoli w czasie podróży pamiętnikarka oswaja zły sen, lecz wciąż chce wierzyć, że to tylko sen:

Po upływie tygodnia wyobraźnia oswoiła się, ciało przywykło, podróż wydała się jakby snem normalnym: siadalo się do powozu bez niecierpliwości, bez żądzy, bez wstrętu, jak się przystępuje do codziennych zatrudnień życia (Wspomuienia, t. 1, s. 6).

Podobnie jak wcześniejsi pamiętnikarze syberyjscy zwraca uwagę na nadużycia przewodników, żohnierzy, okradanie zesłańców, ale też podkreśla przejawy dobrej woli ze strony prostych żołnierzy oraz mieszkańców Syberii. Odnotowuje wszystkie sytuacje, w których otrzymała jakąkolwiek pomoc podczas uciążliwej podróż:

Po dwóch dobach podróży, wysiadłszy z sani podczas przeprzęgu, weszłam do izby domu pocztowego i padlam na lawkę, aby użyć snu, choćby przez parę godzin; nie usnęłam, bo umyst czuwał mimowolnie pobudzony niespokojnością, ale ciało wpad to w odrętwienie najdoskonalsze. Próżno mój przewodnik, stojąc nade mną, nalegal, aby jechać, utrzymując, że w saniach wyśpię się wybornie; jak koń znarowiony nie chciałaın czy też nie mogłam ruszyć z miejsca. Dozorca poczty Rosjanin, odstawny oficer, widząc mój stan zniemożenia, kazal mojemu przewodnikowi pokazać sobie instrukcje, w których się pokazało, że ponaglania przewodnika były nadużyciem z jego strony. Zwierzchność bowiem, mając wyrozumienie dla plci i wieku, ograniczyla fantazje przewodnika, złagadzając przepisy i wchodząc w różne wypadki. Odstawny oficer czytal instrukcję w mojej przytommości, a tak nadal wiedziałam moje prawa równie jak obowiąz-

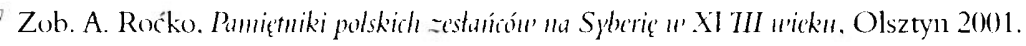


ki. Odtąd podróż była nierównie znośnicjszą; zatrzymywałam się dla snu, skoro uczulam mocne znuzenie (Wspomnicmia, t. 1, s. 6-7).

Szlak zesłańczy Felińskiej prowadzil z Kijowa przez Tułę, Riazań, Kazaí, Perm, Jekaterynburg, Tiumień i Tobolsk. Z Kijowa do Tobolska jechała saniami, kibitką. Ostatni odcinek trasy odbyła statkami. Dwa tygodnie plynęla Obem, a później Sośwą, by wreszcie znaleźć się w Berezowie. Paniętnikarka odnotowuje wszystkie uciążliwości i trudy podróży, ze szczególną odrazą wspomina ogromme ilości owadów, tarakanów, czyli prusaków, na wszystkich kwaterach.

Ewa Feliníska często też opisuje miasta na szlaku zeslania. Jej opisy nie są tak szczegółowe jak innych pamiętnikarzy, ale wynika to z tego, iż, jak sama pisze, widziala miasta tylko „w przejeździe”. Stąd opisy odtwarzane z pamięci są krótkie, zdawkowe, ograniczają się do odnotowania, czy miasto jest murowane, czy też drewniane. Zupehnie inaczej kształtują się deskrypcje przyrody, która wyraźnic fascynowała „podróżniczkę z musu”. I tu ujawnia się literacki talent autorki wspomnień. Większość opisów syberyjskiej natury widzianej na szlaku zesłania przybiera charakter metaforyczny, a czytelnikowi zdaje się, że pamiętnikarka, tworząc je, chociaż na moment zapomina o swym losie i przemienia się z zesłańca w prawdziwego podróżnika. Warto w tym miejscu przytoczyć poetycki opis wiosny, widzianej podczas przeprawy rzeką Irtysz do Berezowa:

15 maja wiosna zaczęła przymilać się pierwszym uśmiechem młodości. Brzozy przy cieplym wietrze powiewały spuszczonymi warkoczami zieloności, walczącej jeszcze z szarością zimy. Już trawka zieleniala, skromne kawałki wiosenne nieśmiało wyścibialy do stońca różnobarwne glówki. Promienie stońca mocno dogrzewaty (Wspommienia, t. 1, s. 47).

Podobne deskrypcje odnajdujemy w dzienniku prowadzonym na bieżąco w Berezowie, do którego przybyła autorka, aby odbyć swoją karę zesłania na osiedlenie, właśnie wiosną:

Berezów jest teraz w catej kokieterii. Modrzewie okryly się mlodymi szpilkami najpowabniejszej zieloności, napełniając powietrze wonią bardzo miłą. Trawa, podsycana wilgocią tającej ziemi, rośnie jak na drożdżach, rośnie prawie widzialnie. Sośwa wezbrana, zalewając nadbrzeże okoliczne, przedstawia oku ogromna przestrzeń wody, która, oblewając wiele wysp wierzbą poroslych, ginie w oddalenie, odbijając tylko w swych nurtach czysty blękit nieba. Blizej bielejące fale, pieniąc się i szumiąc, roztrącają się o brzeg stromy, na którym piętrzy się miasteczko (Wsponmienia, t. 1, s. 81).

Felińska zastanawia się, jak miejsce zesłania moglo wydać jej się tak pięknym, jak mogla pod wpływem natury zapomnieć o swojej tęsknocie, i wówczas wracają w pamięci pejzaże litewskie, a pamiętnikarka thumaczy i analizuje swoją fascynację krajobrazem okolic Berezowa: 
O wiosno mego kraju, wiecznie będę tęsknić za tobą! Jednak muszę wyznać prawdę, że Berezów nie wydal mi się tak okropnym, jak mi zrobiono wyobrażenie. Przysłowie niesie, że i diabeł był pięknym, kiedy był młodym. Tę prawdę można zastosować do okolic. Jestże która brzydką na wiosnę? (Wsponmienia, t. 1, s. 81 ).

Dlatego większość obserwacji oraz opisów poczynionych w Berezowie pamiętnikarka osadza w perspektywie wlasnego krajı, jego obyczajów, mieszkańców, zapamiętanych krajobrazów. Podczas spacerów po lasach w okolicach Berezowa spotyka Ostiaków (Chantów), poznaje ich jurty, zwyczaje oraz codzienne życie. Felińska w bardzo interesujący sposób, z wielką wrażliwością oraz umiejętnością oddała zanikanie kultury rdzennych mieszkańców Syberii pod wpływem rosyjskiego osadnictwa. Pokazala przenikanie się kultur, upadek obyczajów Ostiaków pod wplywem alkoholu, który stał się ich tragedią. Celnie wskazuje na nadużycia kupców, zastraszających uczciwych Ostiaków czy Samojedów, „, narodów początkowej cywilizacji", którzy, wymieniając towar za towar, często nie znają wartości pieniężnej futer, które stanowią ich podstawowe utrzymanie. Jak wskazuje pamiętnikarka, na jednej zamianie żywności, alkoholu, olowiu, noży na cemne skóry kupcy zarabiali czterokrotnie, wykorzystując uczciwość prostych tubylców.

Felińska przytacza też „bajkę ostacka”, nadając jej kształt literacki, wprowadzając dialogi, uwypuklając przesłanie, iż uczciwość zawsze jest nagrodzona, oddaje (podobnie jak wcześniejszy pamiętnikarz Józef Kopeć) ducha rdzennych mieszkańców poznanych syberyjskich przestrzeni. Nic brak też opisów ich wierzeń, szamańskich obrzędów, które wprowadzają czytelnika w świat fascynującej egzotyki. Nie zapomina również Felińska o opisie obyczajów i zwyczajów Berezowian, ich życia codziennego, przesądów, przyzwyczajeń. Wspólczesnego czytelnika uderza przede wszystkim różnica wrażliwości kobiecego opisu realiów życia mieszkańców Syberii a znanego z innych, wcześniejszych przekazów pamiętnikarskich, tworzonych przez mężczyzn. Pamiętnikarze zwracali na przykład uwage na potrawy, kuchnię, ale nigdy nie opisywali kuchni szczególowo. Podkreślali raczej (może poza François-Auguste Thesby de Belcourem, który twierdził, iz rosyjskie potrawy na Syberii „strulyby samego diabla”) interesujące oraz odmienne przyzwyczajenia kulinarne mieszkańców Syberii. Ewa Felińska z niemal reporterską wrażliwością śledzi niewybredny gust kulinarny Berezowian, którzy uwielbiają „kwaśne kaczki” i wszelkie „śmierdzące mięsiwa”:

Uważalam także, jak węch Berezowian nie jest wybredny. Nie tylko, że znoszą po domach czad nieustający, ale jedzą mięsiwa śmierdzące najobrzydliwiej, nie z głodu, ale z wolnego wyboru (IVsommienia, t. 1, s. 271).

Ewa Felińska dzieliła swoje wygnanie z Józefą Rzążewską. Dzięki temu nie była tak bardzo osamotniona jak inni zesłańcy. Nie kłopoty materialne doskwierały jej najbardziej. To tęsknota za dziéćni, obawa o ich los, nieustanne zmaganie z problemem czasu, monotonią, bezsensem wygnańczej egzystencji. Pisanie dziennika stało się więc rodzajem autoterapii, po- 
zwoliło walczyć ze zwątpieniem w powrót do domu i dzieci. Lekarstwem na ogarniająca wszystkich zesłaníców depresję było więc poznawanie życia i obyczajów tubylców, kontakty z Rosjanami, czytanie książek (jeśli były dostępne), urządzanie mieszkania i ogrodu w stylu polskim. Tylko dzięki tym zajęciom możliwe było przetrwanie.

W 1841 rokı Ewa Felińska na mocy amnestii przewieziona została do Saratowa nad Wołga. gdzie przebywała do $184+$ roku. Tam przeżyla śmierć swojej matki oraz córki Pauliny. Uspokojona wizytą syna Zygmunta Szczęsnego, wciąż zajmowała się opisem geograficznym, ekonomicznym, historycznym poznawanego regionu. Nic brak też refleksji społecznych oraz pedagogicznych, obecnych w calym pisarstwie Ewy Felińskiej. I choć autorka uważała, że jej wspomnienia nie zainteresują nikogo, to stanowią doskonałe dopehnienie obrazu Syberii znanego z innych relacji zestańczych z koníca XVIII i z początku XIX wicku:

Wiem, że wypadki tyczące się mnie osobiście nie mogą zajmować nikogo, oprócz może serc bardzo mi bliskich; ależ z życia jednostek czyż nie składa się księga dziejów ludzkości? Są to jej kartki, a kto chce zrozumieć treść tej wielkiej księgi, musi je przebiegnąć (IVspomnicnia, t. 2, s. 6).

Podobne przesłanie towarzyszylo Felińskiej przy pisaniu Pamiçtnikóu żżcia ... po powrocie z zeshania, w Wojutynie. Do dzieci moich — to tytuł wstępu do Pamiętnikóm, w których pisarka, na prośbę swych dzieci, zawarła wspomnienia z dzieciństwa oraz modości, malując z wlasnej perspektywy obraz szlachty kresowej z przełomı XVIII i XIX wicku.

Wydaje się, iż pamiętniki Felińskiej, dziś już zapomniane, powinny wciąż stanowić ważną lekturę przy próbie odtworzenia mentalności i obyczajów mieszkańców litewskich dworków szlacheckich z tego okresu, zwłaszcza że autorka podkreśla, iż ma zamiar

...pisać prawdę bezwzględną, nie przeksztalconą wpływami milości wlasnej, nie ubarwioną wypadkami zmyślonymi dla podniesienia wrażeń,

a jej wspomnienia

...będą mialy zaletę i powab prawdy, zaletę wprawdzie skromną, ale potężną wewnętrzną wartość, niezależną od talentu (Pamiętmiki, t. 1, s. 9).

Warto też wspomnienia Felińskiej odczytać jako obraz przemian obyczajowych oraz społecznych na przełomie stuleci, skreślony ręką sześćdziesięcioletniej pisarki z niezwykłą wnikliwością opisu, trafnością spostrzeżeń oraz bogactwem języka przedstawień. To także świetne studium wychowania, kształcenia oraz możliwości rozwoju kobiet pochodzenia szlacheckiego na kresach wschodnich. Autorka pisze:

Jeżeli te pamiętnikj mogą mieć jaką wartość, wyjąwszy uczuciową, to chyba tę, że przeżywszy lat sześćdziesiąt, dotknąwszy różnych szczeblów towarzystwa, zyjąc w epoce dziwnych i niepospolitych przewrotów, nie tylko w kraju naszym, ale i obcym, byłam świadkiem naocznym, jak nasze towarzystwo, ulega- 
jąc silnym wpływom zewnętrznym i wewnętrznym, nagle się przekształciło, zrzucając dawną postać i przyoblekając nową. Może mi się uda zatrzymać tymi wspomnieniami kilka form, które całkiem znikły z naszej ziemi, a które jednak stanowią ogniwo łączące przyszłość z przeszłością, tłumacząc powód przekształceń, których dziś widzinny shutki, nie pojmując dokładnie przyczyn, które je przygotowaly (Pamię̧tniki, t. 1, s. 6-7).

Najważniejszym przesłaniem, jakie pojawia się na kartach wspomnień,jest glęboka wiara autorki w pielęgnowanie dawnych staropolskich obyczajów, tradycji szlacheckich oraz umiar w przyjmowaniu wszelkich nowości z Zachodu. Równie ważne jest wychowanie w poszanowaniu religii oraz życie zgodne z przykazaniami Boskimi. Szczególnie podkreśla życie w prawdzie i w zgodzie ze swoimi bliskimi. Najważniejsza jest dla pamiętnikarki rodzina, która powinna kultywować tradycje wychowania w poszanowaniu Boga i kształtowaniu więzi między rodzicami i dziećmi.

Felińska wielokrotnie wskazuje, iż tylko staropolska tradycja była w stanie uchronić Polaków od upadku obyczajów i zmian mentalności, które dokonały się pod wpływem źle pojętej, bezkrytycznie przyjmowanej nowej filozofii z Zachodı:

Na całej powierzchni Litwy rewolucja obyczajowa, dziecko filozofii XVIII wieku i próżnowania okolicznościowego, objawia się wstrząśnieniami form rozmaitych. Tu wskutek niewythumaczonego marnotrawstwa padają fortuny, kłócąc się i przeistaczając porządek towarzyski. Tam się rozprzęgają malżeństwa i kojarzą w nowe pary. Gdzie indziej, z pogardą ustaw społecznych i opinii, rodzeństwo, brat z siostrą rozmilowują się w sobie, a nie mogąc otrzymać sankcji religijnej do kazirodczego związku, mieszkają razem, razem dom prowadzą i wychowują wspólnie dzieci. W innym miejscu brat uwodzi żonę brata i bierze ją sobie. Tam wnuczka pada ofiarą zwodnictwa przybranego dziada. Tu matka zastraszona rozpustą, a raczej marnotrawstwem syna, upomina go, aby życie odmienit, nie w imię obowiązku moralnego, ale przedstawiając, że ich wspólny majątek zagrożony ostatecznym upadkiem wymaga zaprowadzenia oszczędności - a syn na to „Już ja dawno myślę o reformie, i chciałem ją właśnie proponować mamie. Niech mama odprawi P. K., a mnie przyjmie na faworyta, to się oszczędzimy oboje" (Pammig̨tniki, t. 3, s. 229-230).

Upadek obyczajów zarówno świeckich, jak i religijnych, upadek moralności doprowadzil do zmian społecznych oraz zachwiania dotąd uznawanych wartości:

W tym zamęcie obyczajowym hierarchia spoleczna ulega szybkiemu rozkładowi, który prowadzi za sobą niepochwycone zmiany. Wielki pan zostaje tulaczem, służalec zostaje panem, magnatka zstępuje w szeregi gminu, kryjąc swoją mitrę pod imię nieznane, a magnat, którego imię zapisane na kartach historii, zmarnowawszy ojcowiznę, bierze w górę młot kowalski i kończy życie filozofícznie. Potęgi moralne, które dotąd kierowaly spoleczeństwem, tracą silę, za- 
gluszone niewstrzymanym pędem oswobodzonych namiętności. Każdy, niby gnany jakimś duchem nieprzyjaznym, kwapi się używać, niszczyć; marnuje, polyka wszystko, jak żeby nie widzial przed sobą żadnej przyszłości, nie widział jutra; a razem polyka życie. Wszystko maleje, traci wartość, więdnieje, usycha; świętości ducha stają się celem szyderstwa (Pamiętniki, t. 3, s. 231).

Oprócz wielu refleksji społecznych we wspomnieniach Felińskiej odnajdziemy także refleksje pedagogiczne. Na podstawie własnych doświadczeń w edukacji, jaką przeszła w domu rodzinnym, a następnie w domu stryjostwa w I Iolynce, przedstawila poglądy na wychowanie i wykształcenie kobiet z warstwy średnicj. Przede wszystkim wskazala, iz jej wykształcenie, wzorowane na wyksztalceniu magnatek (zwłaszcza nauka języka francuskiego, muzyki, tańca), powinno przebiegać nieco inaczej. Powimno się zwracać wiçkszą uwag̨̧ na wybór przedmiotów nauczania potrzebnych kobiecie na prowincji, tak aby potrafiła wypełnić swoje obowiązki względem rodziny i społeczeństwa. Felińska podkreślita apoteozę domu w wychowaniu kobiet, znaczenie dobrego przykładu, wskazała ma ksztaltowanie niezależności w myśleniu, dbanie o kondycję fizyczną przez dlugie spacery na świeżym powietrzu oraz przykładanie większej wagi do doboru lektur mlodej szlachcianki, które powinny być tłumaczone na język polski, tak aby nie tracila sił na przyswajanie sobie obcego języka:

Nauczanie języków obcych zwyklych szlachcianek odzwyczaja je od samodzielnego myślenia. Piękne i pożyteczne książki powinny być tłmmaczone. (...) Gdybyśmy obrócili połowę starań,jakich używają do przyswojenia sobie obcej formy, na wyrobienie własnej i jej udoskonalenie, mielibyśmy cywilizację nie naśladowaną, ale samoistną, zastosowaną do potrzeb wlasnych (I amiçtmiki, t. 2, s. 274-276).

Jadwiga Rudnicka zwraca uwagę, iż poglądy Felińskiej na wychowanie i wykształcenie kobiet z warstwy średniej bliskie są poglądom Klementyny z Tańskich I Ioffmanowej, zawartych w rozprawie O polvinmościach kobiet. Widać też wyraźny wplyw francuskich lektur, z jakimi zetknęła się w domu Wendorffów w I Iolynce, a w szczególności Jana Jakuba Rousseau. Poza tym na jej poglądy na wychowanie oraz na poglądy spoleczne mialy wplyw dzieła spoleczne francuskiego teologa i pedagoga ks. Feliksa Antoniego Filiberta Dupanloup (1802-1878). Jadwiga Rudnicka wskazała, iz Felińska z jego publikacji przethumaczyla niektóre ustępy i zawarła w swoich Pamiętnikadl'.

Pamiętniki z życia Ewy Felińskiej stanowią także bogaty obraz Litwy z przelomu XVIII i XIX wieku. Nie brak w nim opisu malych dworów szlacheckich, znanych Felińskiej z doświadczenia, ale znajdziemy też obraz dworów magnackich, takich jak dwór Radziwilłów w Nieświeżu, a potem w Poloneczce, z barwnymi opisami ogrodów w różnych stylach, architektury, atımosfery tam panującej, od huıcznych zabaw, balów, redut, inienin do działalności

* Zob. J. Ruduicka, op. cit.. s. 199. 
kulturotwórczej, jak na przykład urządzanie przedstawień teatralıych czy deklamacji wierszy okolicznościowych.

Widzimy więc, iż świat wspomnień Ewy Felińskiej z Wendorffów stanowi wciąż doskonalą lekturę nie tylko dla badaczy kultury z przelomu XVIII i XIX wieku, ale też interesujący dokument życia oraz zesłania na Syberię, uwikłanej w zawiłe losy historii, kobiety o interesującej osobowości i wielkiej wrażliwości na poznawany i przeżywany świat. 